\title{
Functional significance of erythropoietin in renal cell carcinoma
}

\author{
Christudas Morais ${ }^{1 *}$, David W Johnson ${ }^{1,2}$, David A Vesey ${ }^{1,2}$ and Glenda C Gobe
}

\begin{abstract}
One of the molecules regulated by the transcription factor, hypoxia inducible factor (HIF), is the hypoxia-responsive hematopoietic factor, erythropoietin (EPO). This may have relevance to the development of renal cell carcinoma (RCC), where mutations of the von Hippel-Lindau (VHL) gene are major risk factors for the development of familial and sporadic RCC. VHL mutations up-regulate and stabilize HIF, which in turn activates many downstream molecules, including EPO, that are known to promote angiogenesis, drug resistance, proliferation and progression of solid tumours. HIFs typically respond to hypoxic cellular environment. While the hypoxic microenvironment plays a critical role in the development and progression of tumours in general, it is of special significance in the case of RCC because of the link between VHL, HIF and EPO. EPO and its receptor, EPOR, are expressed in many cancers, including RCC. This limits the use of recombinant human EPO (rhEPO) to treat anaemia in cancer patients, because the rhEPO may be stimulatory to the cancer. EPO may also stimulate epithelial-mesenchymal transition (EMT) in RCC, and pathological EMT has a key role in cancer progression. In this mini review, we summarize the current knowledge of the role of EPO in RCC. The available data, either for or against the use of EPO in RCC patients, are equivocal and insufficient to draw a definitive conclusion.
\end{abstract}

\section{Background}

Renal cell carcinoma (RCC) accounts for 3\% of all adult cancers, and $90-95 \%$ of neoplasms of the kidney. It is a highly heterogeneous disease with many distinct histologic subtypes [1,2]. Clear cell RCC, arising from the proximal tubular epithelial cells (PTEC) is the most common sporadic subtype constituting $70-80 \%$ of RCC, followed by papillary (10-15\%) and chromophobe (5\%) RCC [3]. RCC can be either familial or sporadic. Both forms are often associated with distinct genetic mutations, of which the most prominent are the von HippelLindau (VHL) gene mutations. The VHL syndrome, which is the result of a germ line mutation in the VHL gene, is the major predisposing factor for familial RCC [4-7]. In sporadic RCC, biallelic inactivation of the VHL gene, either through hyper-methylation or mutation, is the predominant risk factor. The VHL gene is hypermethylated in about $19 \%$ and mutated in $34-56 \%$ of sporadic clear cell RCC [5,8-13]. Clear cell RCC is the

\footnotetext{
* Correspondence: c.morais@uq.edu.au

'Centre for Kidney Disease Research, School of Medicine, University of Queensland at Princess Alexandra Hospital, Building 33, Brisbane, Queensland 4102, Australia

Full list of author information is available at the end of the article
}

leading cause of death in patients with VHL mutations [14]. Despite the recent advancements in the management of RCC patients, death rates have remained unchanged $[15,16]$

\section{The VHL-HIF-EPO pathway}

As the tumour microenvironment is often hypoxic, tumour cells undergo adaptive changes to facilitate their survival. One such survival mechanism under hypoxic conditions is the up-regulation of the transcription factor hypoxia inducible factor (HIF). HIF has two subunits, HIF- $\alpha$ (which has three further subunits HIF- $1 \alpha$, HIF- $2 \alpha$ and HIF- $3 \alpha)$ and HIF- $\beta[17,18]$. While both subunits are constitutively expressed, the tissue levels of HIF- $\alpha$, unlike HIF- $\beta$, are determined by the intracellular oxygen tension. Under normoxic conditions, HIF- $\alpha$ is rapidly degraded, an event largely mediated by a functional VHL [19-23]. The functional protein of VHL, pVHL, forms complexes with elongin $\mathrm{B}$, elongin $\mathrm{C}, \mathrm{Rbx} 1$ and cullin 2 to form a pVHL- E3 ubiquitin ligase complex (pVHL-E3 complex) [24-27]. The pVHL-E3 complex then binds to HIF- $\alpha$, leading to its polyubiquitination and proteasomal degradation [25,28-32] (Figure 1). In the absence of a functional pVHL, secondary to VHL 


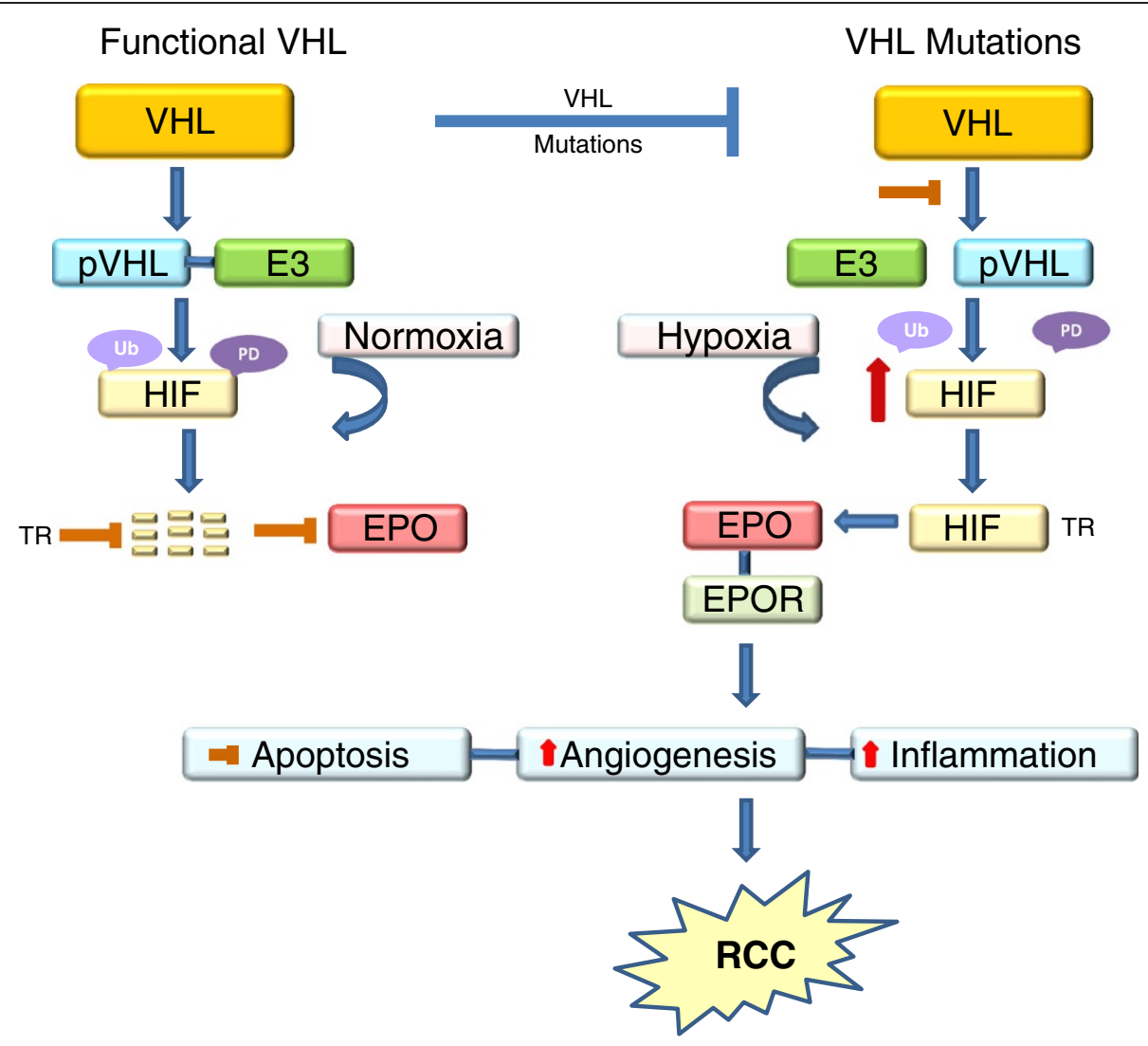

Figure 1 The putative role of VHL-HIF-EPO pathway in RCC progression. A functional VHL gene produces $p V H L$, which forms a pVHL-E3 ligase complex and mediates the poly ubiquitination (Ub) and proteasomal degradation (PD) of HIF. As a result, the translocation (TR) of HIF to the nucleus and the subsequent transactivation of HIF regulated molecules, including EPO is prevented. When the VHL gene is mutated, the production of pVHL and the formation of the pVHL-E3 ligase complex are either impaired or prevented. Subsequently, HIF is stabilized and up-regulated, and translocated to the nucleus, where it dimerizes with other HIF subunits and transactivates HIF responsive genes including EPO. EPO binds to its receptor EPOR and mediates some of the biological aspects of cancer progression such as increase in angiogenesis and inflammation and decrease in intrinsic and druginduced apoptosis. Apart from VHL mutations, hypoxia is the single major factor that regulates the production of EPO. In normoxic conditions, the HIF is degraded, whereas in hypoxia, HIF is stabilized and lead leads to the activation of EPO.

mutations, the formation of the pVHL-E3 complex and its binding to HIF- $\alpha$ are inhibited and therefore, the degradation of HIF- $\alpha$ is prevented even in normoxic conditions [23]. This leads to the stabilization and accumulation of HIF- $\alpha$ in cells. As a result, HIF- $\alpha$ is translocated to the nucleus, where it dimerizes with HIF- $\beta$, binds to hypoxia-responsive elements of the DNA and transactivates many downstream hypoxiainducible molecules that are known to promote angiogenesis, proliferation, drug resistance and tumour progression [6,7,23,25,28] (Figure 1).

One such hypoxia-inducible molecule is the glycoprotein hormone erythropoietin (EPO). Apart from inducing EPO production through HIF, VHL mutations can directly up-regulate EPO without HIF activation [33,34]. Although clear cell RCC is thought to arise from the PTEC, normal PTEC do not express detectable levels of EPO even under hypoxic conditions [35-37]. Therefore, it is believed that VHL mutations play a key role in transforming a non-EPO expressing PTEC into an EPOproducing RCC [35-37]. While the hypoxic trigger of $\mathrm{EPO}$ is a major problem in cancer biology in general, this is of special significance in the case of RCC, because of the direct regulation of EPO by HIF. EPO is the only hematopoietic growth factor whose production is regulated by local hypoxia [38]. If that is the case, EPO is more likely to be a local player in cancer progression, rather than contributor of metastatic progression.

\section{EPO}

The liver is the major site of EPO production in the foetus. At birth, there is a liver to kidney switch and, in adults, the peritubular fibroblasts of the renal cortex are the major sites of EPO production [39-45]. The hepatocytes and perisinusoidal Ito cells of the liver (hepatic stellate cells known for storage of vitamin A) are the major extrarenal sites of EPO production [43-45]. Other than the kidneys and the liver, EPO and EPOR are 
expressed in various non-hematopoietic tissues, such as vascular endothelial cells, the uterus, central nervous system and solid tumours [46]. While EPO is the essential hematopoietic growth factor for erythropoiesis in hematopoietic tissues, in non-hematopoietic tissues, and especially tumours, it inhibits apoptosis, stimulates angiogenesis, promotes drug resistance and increases cell proliferation [47-50]. The biological or oncogenic effects of EPO are mediated through interactions with its receptor, EPOR [51]. The EPO/EPOR interaction activates the cytoplasmic tyrosine kinase, Janus kinase 2 (JAK2), which in turn phosphorylates several cytoplasmic tyrosine residues in the cytoplasmic tail of Epo-R [41,52-55]. The phosphorylated cytoplasmic tail of EPOR acts as a docking site for proteins that contain Srchomology 2 (SH2) domains, for example STAT1, STAT3 and STAT $5 \mathrm{a} / \mathrm{b}$, and initiates a cascade of signalling pathways that either promote erythropoiesis or tumour progression, depending on the target site [41,52-55].

Two important issues remain to be elucidated. First, it is not clear whether or not there is a difference in the production of EPO between RCC with a normal VHL and a mutated VHL. Second, irrespective of any difference in production, it is not clear whether or not there is a difference between the biological activity of EPO produced by a VHL wild type and a VHL mutant RCC.

\section{EPO and EPOR expression in RCC}

Many studies have reported the over expression of EPO and EPOR in human RCC (Table 1 ) especially clear cell RCC [11,50,56-71]. This is because of the high rate of VHL mutations, and the subsequent overproduction and stabilization of HIF in clear cell RCC compared with any other subtypes [37]. RCC cells isolated from patients also express EPO and EPOR in culture [72-79], although conflicting findings have also been reported $[37,58]$. One unresolved issue is the correlation between EPO/EPOR expression and prognosis. With one exception [50], all studies to date [11,56-62] (Table 1) have failed to find an association between EPO/EPOR expression and survival. Despite the frequent expression of EPO and EPOR in RCC, approximately 35\% of RCC patients develop anaemia, whilst only 1-5\% experience paraneoplastic polycythaemia [37,47,62,80-83]. Possible explanations for this seemingly paradoxical finding in the face of elevated EPO blood levels include tumour-induced EPO inactivity (or reduced activity), EPO hyporesponsiveness, iron deficiency and inflammation.

\section{Does the EPO/EPOR pathway have functional significance} in RCC?

Because EPO and EPOR are expressed in RCC (and in other cancers [46]), the use of recombinant human EPO (rhEPO) to treat anaemia in cancer patients has been subject to considerable debate. It is argued that the binding of exogenous rhEPO with EPOR might attenuate tumour growth by decreasing hypoxia (through erythrocyotosis), and thereby HIF, and the subsequent expression of downstream molecules that facilitate angiogenesis and other features of cancer progression [46]. The alternative argument is that binding of exogenous rhEPO with EPOR might, theoretically, initiate autocrine/paracrine effects that will promote tumour progression through inhibiting apoptosis, accelerating proliferation, promoting angiogenesis and enhancing drug resistance [46]. There are data available to support both views.

\section{Beneficial effects of EPO in RCC}

Immunotherapy with interleukin-2 (IL-2), which offers a short term response in $10-15 \%$ of RCC patients, is routinely used in the management of metastatic RCC. A high circulating level of vascular endothelial growth factor (VEGF) has been shown to predict IL-2 resistance in patients with metastatic RCC [84]. As hypoxia is one of the stimulators of VEGF, the correction of anaemia (or anaemia-induced hypoxia) with EPO would counteract

Table 1 Expression of EPO and EPOR in RCC*

\begin{tabular}{|c|c|c|c|c|c|}
\hline Samples & Parameters & Method & Number of samples & $\%$ expression & References \\
\hline Serum & EPO & ELISA & 165 & 33 & {$[57]$} \\
\hline Serum & EPO & ELISA & 49 & 8 & {$[58]$} \\
\hline Tissues & EPO & $\mathrm{IHC} \mathrm{C}^{\#}$ & 19 & 52 & [59] \\
\hline Tissues & EPO \& EPOR & $\mathrm{IHC}$ & 11 & 100 & {$[60]$} \\
\hline Tissues & EPO & $\mathrm{IHC}$ & 20 & 100 & [61] \\
\hline Tissues & EPO & $\mathrm{HC}$ & 113 & 33 & [50] \\
\hline Tissues & EPO & $\mathrm{HC}$ & 82 & 88 & {$[11,56]$} \\
\hline Serum & $E P O \& E P O R$ & $\mathrm{HC}$ & 195 & 83 (tissue EPO) & {$[62]$} \\
\hline \multirow[t]{2}{*}{ Tissues } & & ELISA & & 33 (serum EPO)? & \\
\hline & & & & 56 (tissue EPOR) & \\
\hline
\end{tabular}

*Apart from the publications that are listed in the table, there are many case reports involving one or two patients [63-71].

\#IHC, immunohistochemistry. 
the pro-angiogenic actions of VEGF and reverse IL-2 resistance [85]. Based on these assumptions, in a Phase II trial, Lissoni and colleagues [85] treated metastatic RCC patients, who had already been on IL-2, with a combination of IL-2 and EPO (10,000 units, 3 times a week). Apart from counteracting VEGF-related IL-2 resistance, EPO controlled cancer growth and reduced the toxicity of IL-2. A case report by Rubins [69] shows that treatment with EPO of a large volume metastatic RCC, which was refractory to immunotherapy, resulted in complete remission of all metastatic lesions. A French study that treated 20 patients with subcutaneous EPO for metastatic RCC demonstrated a complete response in one, partial response in three and disease stabilization in ten patients [86]. Janik and colleagues [87] reported that two polycythemic patients with EPO-producing RCC obtained partial or complete response to a combination of IL-2 and interferon- $\alpha$ treatment, suggesting that EPOproducing RCC may be an indicator of immunotherapy response. Carvalho and colleagues [88] reported that concomitant treatment with EPO enhanced the cytotoxicity of vinblastine and daunorubicin in RCC cell lines. Furthermore primary cultures of RCC transfected with erythropoietin-cDNA were more susceptible to lysis by lymphokine-activated killer cells [89].

\section{Adverse effects of EPO in RCC}

To the best of our knowledge, there are two reports that show adverse effects of EPO in RCC patients. In a case report, Sungur [70] describes of a patient who developed local recurrence of RCC while on EPO treatment. The patient had a left radical nephrectomy for RCC and the disease recurred 2 years later in the right kidney, for which a partial nephrectomy was performed. Subsequently, the patient received hemodialysis three times per week along with EPO, 12000U/week, for the first 6 weeks and then a maintenance dose of 4000U/week for 1 year [70]. Fourteen months later, ultrasonography showed a recurrent tumour in the adrenal gland, which was cured by right adrenalectomy. Interestingly through, the patient continued on EPO (4000 u/WK) and remained tumour-free for more than 9 months. Given the case history, it is difficult to conclude whether EPO was the cause of the recurrent tumour. Apart from this report, in the French study mentioned above [86], the remaining six of the 20 patients displayed progressive disease in response to EPO. In vitro studies from our laboratory showed that RCC cells treated with EPO developed resistance to cisplatin treatment [49].

Although not in RCC, it is worth mentioning the adverse effects of EPO administration in other cancers, especially breast cancer and head and neck cancer. In breast cancer, a phase III study on the use of EPO was stopped because of increased mortality, tumour progression and increased incidence of thrombotic and vascular events [90]. In a double-blind, placebo-controlled study, Henke and colleagues reported a poorer outcome for head and neck cancer patients who were treated with EPO [91]. These studies prompted the FDA to issue a black box warning on the use of EPO or erythroid-stimulating agents in cancer patients [92]. A review by Hadland and Longmore details the potential dangers of erythroid-stimulating agents in cancer therapy [93].

None of the clinical trials has explored the molecular mechanism of the EPO-mediated adverse events. While such mechanisms will undoubtedly be multifactorial, one common pathway by which HIF and EPO could potentially enhance cancer progression is by phosphatidylinositol3-kinase/Protein kinase B/mammalian target of rapamycin (PI3K/Akt/mTOR)-mediated EMT. This is best known in head and neck cancer but may well apply to RCC as well. HIF plays a crucial role in EMT of cancer cells and the PI3K/Akt/mTOR pathway plays a central role in this process. Both HIF and EPO activate this pathway. Phosphorylation of PI3K leads to the activation of Akt, which in turn activates mTOR [94,95]. This can be executed directly by HIF per se or through one of the many pro-inflammatory cytokines that are up-regulated in cancer patients, for example tumour necrosis factor- $\alpha$ [94-97]. To support this view, two recent studies have shown that hypoxia induced-EPO [98] and exogenous rhEPO [99] activate the PI3K/Akt/mTOR in retinal, and head and neck cancer cells respectively.

\section{Neutral effects of EPO in RCC}

There is at least one study that shows a neutral effect of EPO in cultured RCC cell lines. Treatment of 22 different cell lines, including 2 RCC cell lines, with rhEPO (dose range $0.01-100 \mathrm{U} / \mathrm{ml}$ ) did not induce any significant changes in clonal growth or proliferation. Furthermore, a neutralizing anti-human EPO antibody had no effect on the clonal growth of these RCC cell lines thereby ruling out any autocrine effects of EPO [100].

\section{Conclusions and future directions}

EPO is of special interest in RCC because of its direct regulation by the VHL-HIF pathway. As rhEPO is widely used in clinical practice for the treatment of anaemia associated with various disorders including cancer, the expression of EPO and EPOR in the kidney and especially in RCC has been a cause for concern. There are two schools of thought. One argues that exogenous rhEPO would correct hypoxia by increasing oxygenation, and therefore, would prevent or stabilize cancer progression. The other school argues that the binding of rhEPO with EPOR would enhance the progression of cancer. While each view has its own merit, a review of the available information on RCC is inconclusive. There are 
many reasons for this. First, and perhaps the most important, is the lack of an adequate number of studies. This is surprising given the direct link between RCC and VHL mutations, the direct or indirect regulation of EPO expression by VHL and the involvement of HIF. Second, the sample size of the available studies is inadequate to evaluate the prognostic significance of EPO and EPOR expression in RCC. Third, the effects of EPO administration in RCC patients (or in other cancers), either beneficial or adverse, cannot be correlated to the expression status of EPO or EPOR, because the criteria for patient selection were not based on the expression status of either of these molecules, and to date no studies have explored this aspect. More comprehensive studies using human samples are warranted. In particular, further information on the baseline level of EPO and EPOR in RCC would be of value in monitoring the effect of exogenous rhEPO on the progression of RCC.

\section{Abbreviations}

EMT: Epithelial-mesenchymal transition; EPO: Erythropoietin;

EPOR: Erythropoietin receptor; HIF: Hypoxia-inducible factor; IL-2: Interleukin-

2; PTEC: Proximal tubular epithelial cells; RCC: Renal cell carcinoma;

rhEPO: Recombinant human erythropoietin; VEGF: Vascular endothelial growth factor; VHL: von Hipple-Lindau.

\section{Competing interests}

Professor David Johnson is a current recipient of a Queensland Government Health Research Fellowship. He has received consultancy fees, research funds, speaking honoraria and travel sponsorships from Jannsen-Cilag, Amgen, Pfizer and Roche. All other authors verify that they have nothing to disclose.

\section{Authors' contributions}

CM and GCG contributed to the conception of the idea, literature search and drafting the manuscript. DWJ and DAV contributed to the interpretation of findings, critical evaluation and editing of the manuscript. All authors critically reviewed and accepted the final version of the manuscript.

\section{Acknowledgements}

The National Health and Medical Research Council (NHMRC) of Australia is acknowledged for providing funding for the salary of Dr Christudas Morais (Project Grant Number 631576).

\section{Author details}

${ }^{1}$ Centre for Kidney Disease Research, School of Medicine, University of Queensland at Princess Alexandra Hospital, Building 33, Brisbane, Queensland 4102, Australia. ${ }^{2}$ Department of Renal Medicine, The University of Queensland at Princess Alexandra Hospital, Brisbane, Queensland 4102, Australia.

Received: 9 August 2012 Accepted: 18 December 2012 Published: 10 January 2013

\section{References}

1. Eble J, Sauter G, Epstein J, Sesterhenn I: Pathology and genetics. Tumours of the urinary system and male genital organs. Lyon: IARC Press; 2001.

2. Lopez-Beltran A, Scarpelli M, Montironi R, Kirkali Z: 2004 WHO classification of the renal tumors of the adults. Eur Urol 2006, 49(5):798-805.

3. Curti BD: Renal cell carcinoma. JAMA 2004, 292(1):97-100.

4. Seizinger BR, Rouleau GA, Ozelius LJ, Lane AH, Farmer GE, Lamiell JM, Haines J, Yuen JW, Collins D, Majoor-Krakauer D, et al: Von Hippel-Lindau disease maps to the region of chromosome 3 associated with renal cell carcinoma. Nature 1988, 332(6161):268-269.

5. Kim WY, Kaelin WG: Role of VHL gene mutation in human cancer. J Clin Oncol 2004, 22(24):4991-5004.
6. Clark PE: The role of VHL in clear-cell renal cell carcinoma and its relation to targeted therapy. Kidney Int 2009, 76(9):939-945.

7. Ohh M, Kaelin WG Jr: VHL and kidney cancer. Methods Mol Biol 2003 , 222:167-183.

8. Arai $E$, Kanai $Y$ : Genetic and epigenetic alterations during renal carcinogenesis. Int J Clin Exp Pathol 2010, 4(1):58-73.

9. Herman JG, Latif F, Weng Y, Lerman MI, Zbar B, Liu S, Samid D, Duan DS, Gnarra JR, Linehan WM, et al: Silencing of the VHL tumor-suppressor gene by DNA methylation in renal carcinoma. Proc Natl Acad Sci USA 1994, 91(21):9700-9704.

10. Kondo K, Yao M, Yoshida M, Kishida T, Shuin T, Miura T, Moriyama M, Kobayashi K, Sakai N, Kaneko S, et al: Comprehensive mutational analysis of the VHL gene in sporadic renal cell carcinoma: relationship to clinicopathological parameters. Genes Chromosomes Cancer 2002, 34(1):58-68.

11. Gong K, Zhang N, Zhang Z, Na Y: Coexpression of erythopoietin and erythopoietin receptor in sporadic clear cell renal cell carcinoma. Cancer Biol Ther 2006, 5(6):582-585.

12. Prowse AH, Webster AR, Richards FM, Richard S, Olschwang S, Resche F, Affara NA, Maher ER: Somatic inactivation of the VHL gene in Von Hippel-Lindau disease tumors. Am J Hum Genet 1997, 60(4):765-771.

13. Brauch $H$, Weirich $G$, Brieger J, Glavac D, Rodl H, Eichinger M, Feurer M, Weidt E, Puranakanitstha C, Neuhaus C, et al: VHL alterations in human clear cell renal cell carcinoma: association with advanced tumor stage and a novel hot spot mutation. Cancer Res 2000, 60(7):1942-1948.

14. Hes FJ, Hoppener JW, Lips CJ: Clinical review 155: Pheochromocytoma in Von Hippel-Lindau disease. J Clin Endocrinol Metab 2003, 88(3):969-974.

15. Jonasch E, Futreal PA, Davis IJ, Bailey ST, Kim WY, Brugarolas J, Giaccia AJ Kurban G, Pause A, Frydman J, et al: State of the science: an update on renal cell carcinoma. Mol Cancer Res 2012, 10(7):859-880.

16. Procopio G, Verzoni E, lacovelli R, Guadalupi V, Gelsomino F, Buzzoni R: Targeted therapies used sequentially in metastatic renal cell cancer: overall results from a large experience. Expert Rev Anticancer Ther 2011 11(11):1631-1640.

17. Wang $G L$, Jiang BH, Rue EA, Semenza GL: Hypoxia-inducible factor 1 is a basic-helix-loop-helix-PAS heterodimer regulated by cellular $\mathrm{O} 2$ tension. Proc Natl Acad Sci USA 1995, 92(12):5510-5514.

18. Kaluz S, Kaluzova M, Stanbridge EJ: Does inhibition of degradation of hypoxia-inducible factor (HIF) alpha always lead to activation of HIF? Lessons learnt from the effect of proteasomal inhibition on HIF activity. J Cell Biochem 2008, 104(2):536-544.

19. Semenza GL: Regulation of mammalian $\mathrm{O} 2$ homeostasis by hypoxiainducible factor 1. Annu Rev Cell Dev Biol 1999, 15:551-578.

20. Huang LE, Bunn HF: Hypoxia-inducible factor and its biomedical relevance. J Biol Chem 2003, 278(22):19575-19578.

21. Maynard MA, Ohh M: Von Hippel-Lindau tumor suppressor protein and hypoxia-inducible factor in kidney cancer. Am J Nephrol 2004, 24(1):1-13.

22. Maynard MA, Qi H, Chung J, Lee EH, Kondo Y, Hara S, Conaway RC, Conaway JW, Ohh M: Multiple splice variants of the human HIF-3 alpha locus are targets of the von Hippel-Lindau E3 ubiquitin ligase complex. J Biol Chem 2003, 278(13):11032-11040.

23. Baldewijns MM, Van VIJ, Vermeulen PB, Soetekouw PM, Van EM, De BAP: VHL and HIF signalling in renal cell carcinogenesis. J Pathol 2010, 221(2):125-138.

24. Stebbins CE, Kaelin WG Jr, Pavletich NP: Structure of the VHL-ElonginCElonginB complex: implications for VHL tumor suppressor function. Science 1999, 284(5413):455-461.

25. Ohh M, Park CW, Ivan M, Hoffman MA, Kim TY, Huang LE, Pavletich N, Chau $\checkmark$, Kaelin WG: Ubiquitination of hypoxia-inducible factor requires direct binding to the beta-domain of the von Hippel-Lindau protein. Nat Cell Biol 2000, 2(7):423-427.

26. Kaelin WG: The von Hippel-Lindau tumor suppressor protein: roles in cancer and oxygen sensing. Cold Spring Harb Symp Quant Biol 2005, 70:159-166.

27. Tanimoto K, Makino Y, Pereira T, Poellinger L: Mechanism of regulation of the hypoxia-inducible factor-1 alpha by the von Hippel-Lindau tumor suppressor protein. EMBO J 2000, 19(16):4298-4309.

28. Ohh M: Ubiquitin pathway in VHL cancer syndrome. Neoplasia 2006 , 8(8):623-629.

29. Maxwell PH, Wiesener MS, Chang GW, Clifford SC, Vaux EC, Cockman ME, Wykoff CC, Pugh CW, Maher ER, Ratcliffe PJ: The tumour suppressor protein VHL targets hypoxia-inducible factors for oxygen-dependent proteolysis. Nature 1999, 399(6733):271-275. 
30. Jaakkola P, Mole DR, Tian YM, Wilson MI, Gielbert J, Gaskell SJ, Kriegsheim A, Hebestreit HF, Mukherji M, Schofield CJ, et al: Targeting of HIF-alpha to the von Hippel-Lindau ubiquitylation complex by O2-regulated prolyl hydroxylation. Science 2001, 292(5516):468-472.

31. Salceda S, Caro J: Hypoxia-inducible factor 1alpha (HIF-1alpha) protein is rapidly degraded by the ubiquitin-proteasome system under normoxic conditions. Its stabilization by hypoxia depends on redox-induced changes. J Biol Chem 1997, 272(36):22642-22647.

32. Huang LE, Gu J, Schau M, Bunn HF: Regulation of hypoxia-inducible factor 1alpha is mediated by an 02-dependent degradation domain via the ubiquitin-proteasome pathway. Proc Natl Acad Sci USA 1998, 95(14):7987-7992.

33. Rankin EB, Tomaszewski JE, Haase VH: Renal cyst development in mice with conditional inactivation of the von Hippel-Lindau tumor suppressor. Cancer Res 2006, 66(5):2576-2583.

34. Rad FH, Ulusakarya A, Gad S, Sibony M, Juin F, Richard S, Machover D, Uzan $\mathrm{G}$ : Novel somatic mutations of the VHL gene in an erythropoietinproducing renal carcinoma associated with secondary polycythemia and elevated circulating endothelial progenitor cells. Am J Hematol 2008, 83(2):155-158

35. Wiesener MS, Eckardt KU: Erythropoietin, tumours and the von HippelLindau gene: towards identification of mechanisms and dysfunction of oxygen sensing. Nephrol Dial Transplant 2002, 17(3):356-359.

36. Wiesener MS, Seyfarth M, Warnecke $C$, Jurgensen JS, Rosenberger $C$, Morgan NV, Maher ER, Frei U, Eckardt KU: Paraneoplastic erythrocytosis associated with an inactivating point mutation of the von Hippel-Lindau gene in a renal cell carcinoma. Blood 2002, 99(10):3562-3565.

37. Wiesener MS, Munchenhagen $P$, Glaser M, Sobottka BA, Knaup KX, Jozefowski K, Jurgensen JS, Roigas J, Warnecke C, Grone HJ, et al: Erythropoietin gene expression in renal carcinoma is considerably more frequent than paraneoplastic polycythemia. Int J Cancer 2007, 121(11):2434-2442.

38. Lacombe C, Mayeux P: The molecular biology of erythropoietin. Nephrol Dial Transplant 1999, 14(Suppl 2):22-28.

39. Fisher JW, Koury S, Ducey T, Mendel S: Erythropoietin production by interstitial cells of hypoxic monkey kidneys. Br J Haematol 1996, 95(1):27-32.

40. Koury ST, Bondurant MC, Koury MJ: Localization of erythropoietin synthesizing cells in murine kidneys by in situ hybridization. Blood 1988, 71(2):524-527.

41. Chateauvieux S, Grigorakaki C, Morceau F, Dicato M, Diederich M: Erythropoietin, erythropoiesis and beyond. Biochem Pharmacol 2011, 82(10):1291-1303.

42. Lacombe C, Da SJL, Bruneval P, Fournier JG, Wendling F, Casadevall N, Camilleri JP, Bariety J, Varet B, Tambourin P: Peritubular cells are the site of erythropoietin synthesis in the murine hypoxic kidney. J Clin Invest 1988, 81(2):620-623.

43. Eckardt KU: Erythropoietin production in liver and kidneys. Curr Opin Nephrol Hypertens 1996, 5(1):28-34.

44. Zanjani ED, Ascensao JL, McGlave PB, Banisadre M, Ash RC: Studies on the liver to kidney switch of erythropoietin production. J Clin Invest 1981, 67(4):1183-1188

45. Lacombe C, Da SJL, Bruneval P, Casadevall N, Camilleri JP, Bariety J, Tambourin $\mathrm{P}$, Varet B: Erythropoietin: sites of synthesis and regulation of secretion. Am J Kidney Dis 1991, 18(4 Suppl 1):14-19.

46. Farrell F, Lee A: The erythropoietin receptor and its expression in tumor cells and other tissues. Oncologist 2004, 9(Suppl 5):18-30.

47. Westenfelder C, Baranowski RL: Erythropoietin stimulates proliferation of human renal carcinoma cells. Kidney Int 2000, 58(2):647-657.

48. Ribatti D, Presta M, Vacca A, Ria R, Giuliani R, Dell'Era P, Nico B, Roncali L, Dammacco F: Human erythropoietin induces a pro-angiogenic phenotype in cultured endothelial cells and stimulates neovascularization in vivo. Blood 1999, 93(8):2627-2636.

49. Li J, Vesey DA, Johnson DW, Gobe G: Erythropoietin reduces cisplatininduced apoptosis in renal carcinoma cells via a PKC dependent pathway. Cancer Biol Ther 2007, 6(12):1944-1950.

50. Michael A, Politi E, Havranek E, Corbishley C, Karapanagiotou L, Anderson C, Relph K, Syrigos KN, Pandha H: Prognostic significance of erythropoietin expression in human renal cell carcinoma. BJU Int 2007, 100(2):291-294.

51. Mulcahy L: The erythropoietin receptor. Semin Oncol 2001, 28(2 Suppl 8):19-23.

52. Witthuhn BA, Quelle FW, Silvennoinen O, Yi T, Tang B, Miura O, Ihle JN: JAK2 associates with the erythropoietin receptor and is tyrosine phosphorylated and activated following stimulation with erythropoietin. Cell 1993, 74(2):227-236.
53. Frank SJ: Receptor dimerization in $\mathrm{GH}$ and erythropoietin action-it takes two to tango, but how? Endocrinology 2002, 143(1):2-10

54. Bao H, Jacobs-Helber SM, Lawson AE, Penta K, Wickrema A, Sawyer ST: Protein kinase B (c-Akt), phosphatidylinositol 3-kinase, and STAT5 are activated by erythropoietin (EPO) in HCD57 erythroid cells but are constitutively active in an EPO-independent, apoptosis-resistant subclone (HCD57-SREl cells). Blood 1999, 93(11):3757-3773.

55. Wojchowski DM, Gregory RC, Miller CP, Pandit AK, Pircher TJ: Signal transduction in the erythropoietin receptor system. Exp Cell Res 1999, 253(1):143-156.

56. Gong K, Zhang N, Zhang K, Na Y: The relationship of erythropoietin overexpression with von Hippel-Lindau tumour suppressor gene mutations between hypoxia-inducible factor-1alpha and -2alpha in sporadic clear cell renal carcinoma. Int J Mol Med 2010, 26(6):907-912.

57. Ljungberg B, Rasmuson T, Grankvist K: Erythropoietin in renal cell carcinoma: evaluation of its usefulness as a tumor marker. Eur Urol 1992, 21(2):160-163.

58. Gross AJ, Wolff M, Fandrey J, Miersch WD, Dieckmann KP, Jelkmann W: Prevalence of paraneoplastic erythropoietin production by renal cell carcinomas. Clin Investig 1994, 72(5):337-340.

59. Clark D, Kersting R, Rojiani AM: Erythropoietin immunolocalization in renal cell carcinoma. Mod Pathol 1998, 11(1):24-28.

60. Lee YS, Vortmeyer AO, Lubensky IA, Vogel TW, Ikejiri B, Ferlicot S, Benoit G, Giraud S, Oldfield EH, Linehan WM, et al: Coexpression of erythropoietin and erythropoietin receptor in von Hippel-Lindau disease-associated renal cysts and renal cell carcinoma. Clin Cancer Res 2005, 11(3):1059-1064.

61. Butnor K, Nicholson AG, Allred DC, Zander DS, Henderson DW, Barrios R, Haque AK, Allen TC, Killen DE, Cagle PT: Expression of renal cell carcinoma-associated markers erythropoietin, CD10, and renal cell carcinoma marker in diffuse malignant mesothelioma and metastatic renal cell carcinoma. Arch Pathol Lab Med 2006, 130(6):823-827.

62. Papworth K, Bergh A, Grankvist K, Ljungberg B, Rasmuson T: Expression of erythropoietin and its receptor in human renal cell carcinoma. Tumour Biol 2009, 30(2):86-92.

63. Murphy GP, Kenny GM, Mirand EA: Erythropoietin levels in patients with renal tumors or cysts. Cancer 1970, 26(1):191-194.

64. Noguchi Y, Goto T, Yufu Y, Uike N, Hasegawa Y, Fukuda T, Jimi A, Funakoshi A: Gene expression of erythropoietin in renal cell carcinoma. Intern Med 1999, 38(12):991-994.

65. Nielsen OJ, Jespersen FF, Hilden M: Erythropoietin-induced secondary polycythemia in a patient with a renal cell carcinoma. A case report. Apmis 1988, 96(8):688-694.

66. Hanada T, Mimata H, Ohno H, Nasu N, Nakagawa M, Nomura Y: Erythropoietin-producing renal cell carcinoma arising from acquired cystic disease of the kidney. Int J Urol 1998, 5(5):493-494. discussion 495.

67. Toyama K, Fujiyama N, Suzuki H, Chen TP, Tamaoki N, Ueyama Y: Erythropoietin levels in the course of a patient with erythropoietinproducing renal cell carcinoma and transplantation of this tumor in nude mice. Blood 1979, 54(1):245-253.

68. Burk JR, Lertora JJ, Martinez IR Jr, Fisher JW: Renal cell carcinoma with erythrocytosis and elevated erythropoietic stimulatory activity. South Med J 1977, 70(8):955-958.

69. Rubins J: Metastatic renal cell carcinoma: response to treatment with human recombinant erythropoietin. Ann Intern Med 1995, 122(9):676-677.

70. Sungur C: Renal cell carcinoma and erythropoietin. Ann Intern Med 1995, 123(9):732-733.

71. Talmon GA: Pure erythropoiesis in clear cell renal cell carcinoma. Int J Surg Pathol 2010, 18(6):544-546.

72. Murphy GP, Brendler H, Mirand EA: Erythropoietin release from renal cell carcinomas grown in tissue culture. Res Commun Chem Pathol Pharmacol 1970, 1(5):617-626.

73. Sherwood JB, Goldwasser E: Erythropoietin production by human renal carcinoma cells in culture. Endocrinology 1976, 99(2):504-510.

74. Shouval D, Sherwood JB: Production of erythropoietin by an established human renal carcinoma cell line: in vitro and in vivo studies. Adv Exp Med Biol 1988, 241:319-328

75. Sherwood JB, Shouval D: Continuous production of erythropoietin by an established human renal carcinoma cell line: development of the cell line. Proc Natl Acad Sci USA 1986, 83(1):165-169.

76. Hagiwara M, Chen IL, McGonigle R, Beckman B, Kasten FH, Fisher JW: Erythropoietin production in a primary culture of human renal carcinoma cells maintained in nude mice. Blood 1984, 63(4):828-835. 
77. Katsuoka Y, McGonigle R, Rege AB, Beckman B, Fisher JW: Erythropoietin production in human renal carcinoma cells passaged in nude mice and in tissue culture. Gann 1983, 74(4):534-541.

78. Okabe T, Urabe A, Kato T, Chiba S, Takaku F: Production of erythropoietinlike activity by human renal and hepatic carcinomas in cell culture. Cancer 1985, 55(9):1918-1923.

79. Sytkowski AJ, Richie JP, Bicknell KA: New human renal carcinoma cell line established from a patient with erythrocytosis. Cancer Res 1983, 43(3):1415-1419.

80. Magera JS Jr, Leibovich BC, Lohse CM, Sengupta S, Cheville JC, Kwon ED, Blute ML: Association of abnormal preoperative laboratory values with survival after radical nephrectomy for clinically confined clear cell renal cell carcinoma. Urology 2008, 71(2):278-282.

81. Nseyo UO, Williams PD, Murphy GP: Clinical significance of erythropoietin levels in renal carcinoma. Urology 1986, 28(4):301-306.

82. Motzer RJ, Bander NH, Nanus DM: Renal-cell carcinoma. N Engl J Med 1996, 335(12):865-875

83. Da SJL, Lacombe C, Bruneval P, Casadevall N, Leporrier M, Camilleri JP, Bariety J, Tambourin P, Varet B: Tumor cells are the site of erythropoietin synthesis in human renal cancers associated with polycythemia. Blood 1990, 75(3):577-582.

84. Blay JY, Pallard M, Ravaud A: Serum VEGF is an independent prognostic factor in patients with metastatic renal cell carcinoma treated with IL-1 and/or IFN: analysis of the Crecy trial. Proc Am Ass Clin Oncol (Abstr) 1997, 18.

85. Lissoni P, Rovelli F, Baiocco N, Tangini G, Fumagalli L: A phase II study of subcutaneous low-dose interleukin-2 plus erythropoietin in metastatic renal cell carcinoma progressing on interleukin-2 alone. Anticancer Res 2001, 21(1B):777-779.

86. Morere JF, Bouillet T, Piperno-Neumann S, Tourani JM, Brunet A, Hennebelle F, Bareau JL: Treatment of advanced kidney cancer using recombinant erythropoietin. Prog Urol 1997, 7(3):399-402.

87. Janik JE, Sznol M, Urba WJ, Figlin R, Bukowski RM, Fyfe G, Pierce WC, Belldegrun A, Sharfman WH, Smith JW 2nd, et al: Erythropoietin production. A potential marker for interleukin-2/interferon-responsive tumors. Cancer 1993, 72(9):2656-2659.

88. Carvalho G, Lefaucheur C, Cherbonnier C, Metivier D, Chapel A, Pallardy M, Bourgeade MF, Charpentier B, Hirsch F, Kroemer G: Chemosensitization by erythropoietin through inhibition of the NF-kappaB rescue pathway. Oncogene 2005, 24(5):737-745.

89. Miyajima J, Imai Y, Nakao M, Noda S, Itoh K: Higher susceptibility of erythropoietin-producing renal cell carcinomas to lysis by lymphokineactivated killer cells. J Immunother Emphasis Tumor Immunol 1996, 19(6):399-404.

90. Leyland-Jones B: Breast cancer trial with erythropoietin terminated unexpectedly. Lancet Oncol 2003, 4(8):459-460.

91. Henke M, Laszig R, Rube C, Schafer U, Haase KD, Schilcher B, Mose S, Beer $K T$, Burger $U$, Dougherty $C$, et al: Erythropoietin to treat head and neck cancer patients with anaemia undergoing radiotherapy: randomised, double-blind, placebo-controlled trial. Lancet 2003, 362(9392):1255-1260.

92. Information for Healthcare Professionals: Erythropoiesis Stimulating Agents (ESA) [Aranesp (darbepoetin), Epogen (epoetin alfa), and Procrit (epoetin alfa)] (3/2007). http://www.fda.gov/Drugs/DrugSafety/ PostmarketDrugSafetylnformationforPatientsandProviders/ucm 126485.htm.

93. Hadland BK, Longmore GD: Erythroid-stimulating agents in cancer therapy: potential dangers and biologic mechanisms. J Clin Oncol 2009, 27(25):4217-4226.

94. Bao B, Azmi AS, Ali S, Ahmad A, Li Y, Banerjee S, Kong D, Sarkar FH: The biological kinship of hypoxia with CSC and EMT and their relationship with deregulated expression of miRNAs and tumor aggressiveness. Biochim Biophys Acta 2012, 1826(2):272-296.

95. Jiang J, Tang YL, Liang XH: EMT: a new vision of hypoxia promoting cancer progression. Cancer Biol Ther 2011, 11(8):714-723.

96. Ho MY, Tang SJ, Chuang MJ, Cha TL, Li JY, Sun GH, Sun KH: TNF-alpha induces epithelial-mesenchymal transition of renal cell carcinoma cells via a GSK3beta-dependent mechanism. Mol Cancer Res 2012, 10(8):1109-1119.

97. Chuang MJ, Sun KH, Tang SJ, Deng MW, Wu YH, Sung JS, Cha TL, Sun GH: Tumor-derived tumor necrosis factor-alpha promotes progression and epithelial-mesenchymal transition in renal cell carcinoma cells. Cancer Sci 2008, 99(5):905-913.

98. Sanghera KP, Mathalone N, Baigi R, Panov E, Wang D, Zhao X, Hsu H, Wang $H$, Tropepe V, Ward M, et al: The PI3K/Akt/mTOR pathway mediates retinal progenitor cell survival under hypoxic and superoxide stress. Mol Cell Neurosci 2011, 47(2):145-153.
99. Abhold E, Rahimy E, Wang-Rodriguez J, Blair KJ, Yu MA, Brumund KT Weisman RA, Ongkeko WM: Recombinant human erythropoietin promotes the acquisition of a malignant phenotype in head and neck squamous cell carcinoma cell lines in vitro. BMC Res Notes 2011, 4:553.

100. Berdel WE, Oberberg D, Reufi B, Thiel E: Studies on the role of recombinant human erythropoietin in the growth regulation of human nonhematopoietic tumor cells in vitro. Ann Hematol 1991, 63(1):5-8.

doi:10.1186/1471-2407-13-14

Cite this article as: Morais et al:: Functional significance of erythropoietin in renal cell carcinoma. BMC Cancer 2013 13:14

\section{Submit your next manuscript to BioMed Central and take full advantage of:}

- Convenient online submission

- Thorough peer review

- No space constraints or color figure charges

- Immediate publication on acceptance

- Inclusion in PubMed, CAS, Scopus and Google Scholar

- Research which is freely available for redistribution

Submit your manuscript at www.biomedcentral.com/submit
C) Biomed Central 